Hemorajik Şokta Farklı Resusitasyon Sıvılarının Erken Dönem Akciğer İskemi Reperfüzyon Hasarı ve İnflamatuvar Yanıt Üzerine Etkileri: Deneysel Çalışma

\title{
Effects of Different Resuscitation Fluids on Early Lung Ischaemia- Reperfusion Injury and Inflammatory Response: An Experimental Study
}

\author{
$\underline{\text { Adem Yüksel }^{1} \text {, Metin Tilki' }}{ }^{2}$, Veli Melih Kara ${ }^{2}$, Ahmet Ozer Sehirli ${ }^{3}$, Selvinaz Özkara ${ }^{4}$ \\ ${ }^{1}$ Kocaeli Derince Eğitim ve Araştırma Hastanesi, Gastroenteroloji Cerrahisi Kliniği, Kocaeli, Türkiye \\ ${ }^{2}$ Haydarpaşa Numune Eğitim ve Araştırma Hastanesi, Genel Cerrahi Kliniği, İstanbul, Türkiye \\ ${ }^{3}$ Yakın Doğu Üniversitesi Diş Hekimliği Fakültesi, Farmakoloji Ana Bilim Dalı, Lefkoşa, Kuzey Kıbrıs Türk Cumhuriyeti \\ ${ }^{4}$ Haydarpaşa Numune Eğitim ve Araştırma Hastanesi, Patoloji Kliniği, İstanbul, Türkiye
}

\begin{abstract}
$\ddot{O} Z$
GIRIŞ ve AMAÇ: Volüm kontrollü hemorajik şok modelinde; kullanılan farkl resusitasyon sivilarinin (3\% hipertonik salin vs ringer laktat vs kan ürünü) erken dönemde akciğer iskemi reperfüzyon hasarı, immun ve inflamatuvar yanit üzerine etkilerinin karșılaștırılması amaçlandl.

YÖNTEM ve GEREÇLER: Yirmi sekiz adet rat 4 gruba ayrildl. Sham grubunda (n: 7) sadece anestezi altında sağ femoral ven eksplorasyonu, damar kanülasyonu ve ardından gözlem yapıldl. Sok gruplarında ise femoral ven kanüle edildi. Hesaplanan total kan hacminin $30 \%$ u kadar kan heparinli enjektöre alınarak ratlarda şok tablosu olușturuldu. Kırk beș dakika sonra HTS grubu (n: 7) $3 \%$ HTS ile $10 \mathrm{ml} / \mathrm{kg}$ dozunda, kan ile replasman grubu ( $\mathrm{n}$ : 7) alınan kanin yarlstyla, ringer laktat grubu ( $\mathrm{n}: 7)$ ise $33 \mathrm{ml} / \mathrm{kg}$ dozunda RL ile replase edildi. Replasmandan 20 dakika sonra tüm şok gruplarında alınan kanın yarısı reinfüze edildi. Hemorajik şok sonrast ratlar 4.saatte sakrifiye edildi. Incelemeler için abdominal aortadan kan örneği, terminal ileum ve sağ akciğerden doku örneği alındl.

BULGULAR: Akciğer dokusunda MDA ve MPO düzeyi, HTS grubunda diğer şok gruplarına göre daha düşük bulundu (MDA, $p<0.05$ kan grubuyla ve $p<0.01 v s$ RL grubuyla; MPO, $p<0.05$ kan grubuyla ve $p<0.01$ RL grubuyla). Glutatyon (GSH) düzeyi ise HTS grubunda diğer şok gruplarına göre daha yüksekti $(p<0.05$ kan grubuyla ve $p<0.01 R L$ grubuyla). Proinflamatuvar sitokinlerden TNF- $\alpha$ ve IL-1 $\beta$ serum düzeyi, HTS grubunda daha düşük olarak bulundu. Histopatolojik değerlendirmede; HTS ile replasman uygulanan grupta, akciğer ve bağırsak hasar skoru diğer şok gruplarına göre daha düşük bulundu.

TARTISSMA ve SONUÇ: Hemorajik şok tedavisinde, HTS (3\%) ile sıvl resusitasyonu; konvansiyonel yaklaşımlara göre akciğerde erken dönem iskemi reperfüzyon hasarını ve sistemik inflamatuvar yanitı azaltır.
\end{abstract}

Anahtar Kelimeler: hemorajik şok, \%3 hipertonik salin, antiinflamatuvar, iskemi-reperfüzyon

\section{ABSTRACT}

INTRODUCTION: The study aimed to compare the effects of different resuscitation fluids (3\% hypertonic saline vs lactated Ringer's solution vs a blood product) on early lung ischaemiareperfusion injury and immune and inflammatory responses in a volume-controlled haemorrhagic shock model.

METHODS: Twenty-eight rats were divided into four groups. In the sham group ( $n: 7)$, right femoral vein exploration, vein cannulation, and observation were performed under anaesthesia. In the shock model groups, the femoral vein was cannulated. Of the calculated total blood volume, 30\% was taken into a heparinized injector to induce the shock model in rats. Forty-five minutes later; the withdrawn blood was replaced by $10 \mathrm{ml} / \mathrm{kg} 3 \%$ hypertonic saline ( $n: 7)$, half of the removed blood (n: 7), and 33 $\mathrm{ml} / \mathrm{kg}$ lactated Ringer solution ( $\mathrm{n}: \mathrm{7})$ in the HTS, blood product, and $R L$ groups, respectively. Half of the total volume of the removed blood was reinfused in all of the shock-induced groups 20 minutes after the replacement. Rats were sacrificed in the fourth hour after the induction of haemorrhagic shock. For examinations; blood samples were collected from the abdominal aorta and tissue samples were collected from the terminal ileum and the right lung. RESULTS: Lung tissue MDA and MPO levels were lower in the HTS group compared to other shock groups (MDA, $p<0.05$ vs the blood group and $p<0.01$ vs RL; MPO, $p<0.05$ vs the blood group and $p<0.01$ vs the RL group). Glutathione levels were higher in the HTS group compared to other shock groups ( $p<0.05$ vs the blood group and $p<0.01$ vs the $R L$ group). Of the proinflammatory cytokines, TNF- $\alpha$ and IL-1 $\beta$ serum levels were lower in the HTS group compared to the other groups. In the histopathological evaluation; lung and intestinal injury scores were lower in the group receiving HTS for replacement compared to the other shock groups.

DISCUSSION AND CONCLUSION: Fluid resuscitation with 3\% hypertonic saline for the treatment of haemorrhagic shock reduces early-stage ischaemia-reperfusion injury and systemic inflammatory response in the lung compared to conventional approaches.

Keywords: haemorrhagic shock, 3\% hypertonic saline, antiinflammatory, ischaemia-reperfusion

Iletişim / Correspondence:

Uzm. Dr. Adem Yüksel

Kocaeli Derince Ĕgitim ve Araştırma Hastanesi, Gastroenteroloji Cerrahisi Kliniği, Kocaeli, Türkiye

E-mail:drademyuksel@gmail.com

Başvuru Tarihi: 09.01.2021

Kabul Tarihi: 14.02.2021 


\section{INTRODUCTION}

Haemorrhagic shock is a form of shock encountered in trauma and surgery patients. Bleeding is the most important cause of the increased risk of morbidity and mortality in haemorrhagic shock patients (1). Impairment of tissue perfusion due to bleeding starts a series of events in the organism resulting in oxidative tissue damage. Bleeding control and adequate intravascular fluid replacement are the mainstay of therapy. However; some patients may develop acute respiratory distress syndrome, systemic inflammatory response syndrome, sepsis, and multiorgan failure despite treatment (2). Associated with the risk of morbidity and mortality, such conditions are thought to be caused by the excessive inflammatory response and immune system suppression occurring during the shock process (3-6). Furthermore, ischaemia-reperfusion (IR) injury occurring during shock and associated therapy are considered active factors involved in the onset and exacerbation of such untoward events (7).

Today, many fluid types with different contents and properties are used for fluid resuscitation in haemorrhagic shock (8). However, the debate continues over which resuscitation fluid has optimal efficacy. Current treatment guidelines recommend the use of crystalloid fluids for resuscitation (9). However; crystalloid fluids need to be administered in high volumes to ensure haemodynamic stability, increasing the risk of neutrophil-mediated lung injury (10). Most of the recent studies about fluid resuscitation have emphasized the importance of preventing the inflammatory response and IR injury developing during haemorrhagic shock $(5,7)$.

Various studies have suggested that small volume resuscitation with $7.5 \%$ hypertonic saline (HTS) is effective for the treatment of haemorrhagic shock (11-13). Furthermore, the antiinflammatory(14) and immunomodulatory (15) effects of HTS may reduce injury to the lungs and intestines. However; the association of HTS (7.5\%) administration with hypernatraemia, hyperchloraemia, cardiac dysrhythmia, and transient hypotension may limit its use (16). HTS $3 \%$ is a solution approved by the FDA for the treatment of hyponatraemia. For the treatment of haemorrhagic shock, HTS 3\% has been shown to be similar in haemodynamic effects to HTS $7.5 \%$ and associated with a lower risk for complications (16).

The study aimed to compare the effects of the lactated Ringer's solution (RL) and HTS (3\%) administered for the treatment of haemorrhagic shock on the inflammatory response, immune system, and pulmonary IR injury in early-stage shock.

\section{MATERIALS AND METHODS}

\section{Ethics:}

The study protocol was approved by the ethical committee on animal experimentation of Marmara University University (62.2010.mar). Animals were treated in compliance with the laboratory animal care and use guidelines developed by the National Institutes of Health.

In this study, 28 male Wistar albino rats weighing 260-280 $\mathrm{g}$ were used. Before the experiment, the animals were fed with standard laboratory feed and water and kept in an environment with regular light-dark cycles.

\section{Experimental Protocol:}

After inhalation exposure to ether, rats were anaesthetized with $50 \mathrm{mg} / \mathrm{kg}$ intramuscular ketamine HCL (Ketalar, Parke Davis, Morris Plains, NJ, USA). Following the skin sterilization with povidone-iodine $10 \%$, the right femoral artery and vein were dissected. The right femoral vein was cannulated with a 28-gauge polyethylene intravenous catheter. The total blood volumes of rats were calculated using the $61 \mathrm{ml} / \mathrm{kg}$ formula (17). Thirty per cent of the calculated total blood volume was taken inside a heparinized injector over a period of 10 minutes. Fluid replacement started 45 minutes later. Fluid replacement was performed over a period of 10 minutes using a different type of fluid in each group. Twenty minutes after the fluid replacement, half of the removed blood was reinfused to the rats over a period of 10 minutes. After the completion of the procedure, the femoral vein was decannulated and ligated. Following the conclusion of the procedures, all rats included in the experiment were kept under observation in an environment suitable for ethical conditions required for laboratories. Rats were sacrificed in the fourth hour after haemorrhagic shock in compliance with laboratory ethics. For biochemical tests, samples of $2 \mathrm{ml}$ blood were collected from the abdominal aorta of the animals. Tissue samples were collected from the terminal ileum and the right lung for histopathological examinations.

\section{Experimental Groups:}

Twenty-eight rats were randomly divided into four groups of 7 . In the sham group, only the procedures of vein exploration and blood vessel cannulation were performed under anaesthesia. After these procedures, the rats were kept under observation. As for fluid replacements; half of the 
total volume of the removed blood, $10 \mathrm{ml} / \mathrm{kg}$ HTS (3\%) (18) and $33 \mathrm{ml} / \mathrm{kg}$ RL (19) were infused over 10 minutes in the blood group, HTS group, and RL group, respectively.

Measurement of Malondialdehyde (MDA) and Glutathione (GSH) Levels in the Lung Tissue:

Tissue samples were homogenized with $10 \%$ trichloroacetic acid (TCA). The homogenized samples were centrifuged at $3000 \mathrm{rpm}$ for 15 minutes. The supernatant was separated and centrifuged at $15000 \mathrm{rpm}$ for 10 minutes. MDA levels were measured by spectrophotometry. GSH levels were determined by a spectrophotometric assay using Ellman's method (20).

Measurement of Myeloperoxidase (MPO) Activity in the Lung Tissue:

Tissue samples were homogenized in HETAB $0.5 \%$ (in $50 \mathrm{mM}$ potassium phosphate buffer with $\mathrm{pH}$ : 6). The samples were centrifuged for 10 minutes. After removing the supernatant, the pellet was rehomogenized in $50 \mathrm{mM}$ potassium phosphate buffer. Laboratory tubes containing $50 \mathrm{mM}$ potassium phosphate buffer + o-Dianisidine -2 HCL $(20 \mathrm{mg} / \mathrm{ml})+\mathrm{H} 2 \mathrm{O} 2(20 \mathrm{mM})+$ the sample were incubated in room temperature for three minutes. Sodium azide $2 \%$ was added to stop the reaction. Spectrometry reading was performed at $460 \mathrm{~nm}$.

Measurement of Serum TNF- $\alpha$ and IL-1 $\beta$ Levels:

A TNF- $\alpha$ rat kit (BioSource Europe S.A. Catalog No. KRC 3014, Nivelles, Belgium) and an IL-1 $\beta$ rat kit (BioSource Catalog No. KRC0011, Nivelles, Belgium) were used to measure serum TNF- $\alpha$ and IL-1 $\beta$ levels via the ELISA method, respectively.

\section{Histopathological Examination:}

Histopathological analyses for this study were performed in the pathology laboratory of Haydarpaşa Numune Training and Research Hospital. Tissue samples embedded in paraffin blocks were processed using the haemotoxylin and eosin stain and Masson trichrome staining methods. For histological grading; the clock positions of 3 o'clock, 6 o'clock, 9 o'clock, and 12 o'clock were marked on the lung and small intestine tissue samples using a grease pencil under the light microscope. The clock positions were examined, scored, and averaged. Oedema, leukocytic infiltrations, lymphocytic infiltrations, and congestion were assessed separately and the scores were averaged. The modified Erlich-Hunt scale was used in histopathological examinations (Table 1) (21).

Table 1. Modified Ehrlich-Hunt Histopathological Grading Scale (21).

\begin{tabular}{|l|l|}
\hline Finding & Score \\
\hline No Evidence & 0 \\
\hline Occasional but scattered & 1 \\
\hline Occasional and available in all areas. & 2 \\
\hline Abundant but scattered & 3 \\
\hline Abundant and available in all areas. & 4 \\
\hline
\end{tabular}

\section{Statistical Analysis:}

SPSS for Windows was used for the statistical analysis of the study data. Categorical variables in independent groups were summarized in median, standard deviation, and mean standard errors. Levene's test was used to evaluate the distribution of data in the groups. One-way ANOVA was used to evaluate the difference between the means of two groups of normally distributed data. Tukey's HSD test was used as a post hoc test to compare groups. To analyze data that conformed to a nonparametric distribution, the Kruskal-Wallis test was used to evaluate intergroup differences and the MannWhitney $\mathrm{U}$ test was used to compare the groups one by one. A p-value of $<0.05$ was considered statistically significant.

\section{RESULTS}

The procedures in the experimental protocol were completed before the death of all of the rats included in the study. An average volume of $4.91 \pm 0.40 \mathrm{ml}$ blood was removed. All procedures were completed in $265 \pm 10$ minutes on the average.

MDA, GSH, and MPO levels in the lung tissue:

MDA levels indicating lipid peroxidation were lower in the HTS group compared to the groups, where blood and RL were used for fluid replacement $(\mathrm{p}<0.05$ and $\mathrm{p}<0.01$, respectively). GSH levels were higher in the HTS group compared to other shock groups ( $p<0.05$ vs the blood group and $\mathrm{p}<0.01$ vs the RL group). MPO 
levels indicating neutrophil infiltration to the tissue were lower in the HTS group compared to other shock groups ( $\mathrm{p}<0.05$ vs the blood group and $\mathrm{p}<0.01$ vs the RL group) (Table 2).

Table 2. Tissue glutathione (GSH), malondialdehyde (MDA), myeloperoxidase (MPO) values of all groups in lung injury induced by shock in rats.

\begin{tabular}{|c|c|c|c|c|}
\hline & $\begin{array}{l}\text { Sham } \\
\text { Group }\end{array}$ & $\begin{array}{l}\text { Blood } \\
\text { Group }\end{array}$ & $\begin{array}{l}\text { HTS } \\
\text { Group }\end{array}$ & RL Group \\
\hline $\begin{array}{l}\text { GSH } \\
(\mathrm{mmol} / \mathrm{g})\end{array}$ & $2.66 \pm 0.20$ & $\begin{array}{l}1.96 \pm 0.08 \\
* *\end{array}$ & $\begin{array}{ll}2.51 \quad \pm \\
0.13^{+}\end{array}$ & $\begin{array}{l}1.78 \pm 0.11 \\
* *,\end{array}$ \\
\hline $\begin{array}{l}\text { MDA } \\
(\mathrm{nmol} / \mathrm{g})\end{array}$ & $\begin{array}{l}16.50 \quad \pm \\
2.19\end{array}$ & $\begin{array}{l}45.61 \pm 5.71 \\
* * *\end{array}$ & $\begin{array}{l}28.13 \pm \\
3.14^{+}\end{array}$ & $\begin{array}{l}\mathbf{4 9 . 0 2} \pm \mathbf{4 . 4 8} \\
* * *,\end{array}$ \\
\hline $\begin{array}{l}\text { MPO } \\
(\mathbf{U} / g)\end{array}$ & $8.36 \pm 1.02$ & $\begin{array}{l}24.26 \pm 2.97 \\
* * *\end{array}$ & $\begin{array}{l}13.82 \pm \\
1.60^{+}\end{array}$ & $\begin{array}{l}27.79 \pm 3.14 \\
* * *,\end{array}$ \\
\hline \multicolumn{5}{|c|}{$\begin{array}{l}\text { Data are expressed as mean } \pm \text { standart derivation }(\mathbf{n}=7) \text {. } \\
* * \mathbf{p}<0,01 ; * * * \mathbf{p}<0,001 \text { Significant differences between sham and other } \\
\text { groups. } \\
+\mathbf{p}<0,05 \text { Significant differences between blood and other groups (HTS, RL). } \\
\square \square \mathbf{p}<0,01 \text { Significant differences between HTS and RL groups. }\end{array}$} \\
\hline
\end{tabular}

\section{Serum TNF- $\alpha$ and IL-1 $\beta$ Levels:}

Increased serum TNF- $\alpha$ levels were observed independent of the treatment applied during the shock process. Such increases were lower in the HTS group compared to the other shock groups. Serum IL-1 $\beta$ levels were lower in the HTS group compared to the RL and blood groups (Table 3 ).

Table 3. Serum TNF- $\alpha$ and IL-1 $\beta$ values of all groups in rats.

\begin{tabular}{|c|c|c|c|c|}
\hline & $\begin{array}{l}\text { Sham } \\
\text { Group }\end{array}$ & Blood Group & HTS Group & RL Group \\
\hline $\begin{array}{l}\text { TNF- } \alpha \\
(\mathrm{pg} / \mathrm{ml})\end{array}$ & $7.53 \pm 1.31$ & $16.60 \pm 1.65 * *$ & $\begin{array}{l}8.60 \pm 1.31 \\
++\end{array}$ & $\begin{array}{l}17.47 \pm 1.55 \\
* * *, \square \square\end{array}$ \\
\hline $\begin{array}{l}\text { IL-1及 } \\
(\mathrm{pg} / \mathrm{ml})\end{array}$ & $\begin{array}{l}16.93 \pm \\
2.65\end{array}$ & $\begin{array}{l}44.83 \pm 2.55 \\
* * *\end{array}$ & $\begin{array}{l}16.62 \pm 1.78 \\
+++\end{array}$ & $\begin{array}{l}45.60 \pm 3.01 \\
* * *, \square \square \square\end{array}$ \\
\hline \multicolumn{5}{|c|}{$\begin{array}{l}\text { Data are expressed as mean } \pm \text { standart derivation }(n=7) \text {. } \\
{ }^{* *} p<0,01 ; * * * p<0,001 \text { Significant differences between sham and } \\
\text { other groups. } \\
++p<0,01 ;+++p<0,001 \text { Significant differences between blood and } \\
\text { other groups (HTS, RL). } \\
\square \square<0,01 ; \square \square p<0,001 \text { Significant differences between HTS and RL } \\
\text { groups. }\end{array}$} \\
\hline
\end{tabular}

\section{Lung Injury Scores:}

Pulmonary injury scores were higher in the groups receiving $\mathrm{RL}$ and blood for fluid replacement compared to the group, where HTS was used for fluid replacement ( $\mathrm{p}<0.05$ vs the blood group and $\mathrm{p}<0.01$ vs the RL group) (Table 4).
Table 4. Comparison of intestinal injury between groups according to histopathological scoring.

\begin{tabular}{|l|l|l|l|l|}
\hline \multirow{2}{*}{ Edema } & $\begin{array}{l}\text { Sham } \\
\text { Group }\end{array}$ & $\begin{array}{l}\text { Blood } \\
\text { Group }\end{array}$ & $\begin{array}{l}\text { HTS } \\
\text { Group }\end{array}$ & RL Group \\
\hline Congestion & 0,5 & 2,5 & 1,5 & 2,5 \\
\hline $\begin{array}{l}\text { Neutrophil } \\
\text { Infiltration }\end{array}$ & 0,38 & 2,38 & 1,38 & 2,25 \\
\hline $\begin{array}{l}\text { Lymphocyte } \\
\text { Infiltration }\end{array}$ & 0,62 & 2,12 & 1 & 2 \\
\hline Total Score & 0,5 & 2,5 & 1,38 & 2,25 \\
& $\mathbf{2} \pm \mathbf{0 , 2}$ & $\mathbf{9 , 5} \pm \mathbf{0 , 2 * *}$ & $\mathbf{5 , 2 6} \pm$ & $\mathbf{9} \pm \mathbf{0 , 3}$ \\
\hline
\end{tabular}

Data are expressed as mean \pm standart derivation $(n=7)$.

** $\mathrm{p}<0,01$; ${ }^{* *} \mathrm{p}<0,001$ Significant differences between sham and other groups.

$+p<0,05$ Significant differences between blood and other groups (HTS, RL).

때 $<<0,01$ Significant differences between HTS and RL groups.

\section{Intestinal Injury Scores:}

Intestinal injury was less severe in the group receiving HTS for replacement compared to the other shock groups ( $p<0.05$ vs the blood group and $\mathrm{p}<0.01$ vs the RL group) (Table 5).

Table 5. Comparison of lung injury between groups according to histopathological scoring.

\begin{tabular}{|c|c|c|c|c|}
\hline & $\begin{array}{l}\text { Sham } \\
\text { Group }\end{array}$ & $\begin{array}{l}\text { Blood } \\
\text { Group }\end{array}$ & HTS Group & RL Group \\
\hline Edema & 0,25 & 0,625 & 0,5 & 1 \\
\hline Congestion & 0 & 0,125 & 0,125 & 0,625 \\
\hline $\begin{array}{l}\text { Neutrophil } \\
\text { Infiltration }\end{array}$ & 0,25 & 1,375 & 0,375 & 1,375 \\
\hline $\begin{array}{l}\text { Lymphocyte } \\
\text { Infiltration }\end{array}$ & 0,375 & 1,125 & 0,875 & 0,625 \\
\hline Total Score & $0,875 \pm 0,2$ & $3,25 \pm 0,2^{* *}$ & $1,875 \pm 0,2^{+}$ & $\begin{array}{l}3,625 \pm 0,3^{* * *}, \\
\square\end{array}$ \\
\hline \multicolumn{5}{|c|}{$\begin{array}{l}\text { Data are expressed as mean } \pm \text { standart derivation }(\mathrm{n}=7) \text {. } \\
* * \mathbf{p}<0,01 ; * * * \mathbf{p}<0,001 \text { Significant differences between sham and } \\
\text { other groups. } \\
+\mathbf{p}<0,05 \text { Significant differences between blood and other groups } \\
\text { (HTS, RL). } \\
\square \square \text { p }<0,01 \text { Significant differences between HTS and RL groups. }\end{array}$} \\
\hline
\end{tabular}

\section{DISCUSSION}

IR injury is an important factor in the development of systemic inflammatory response syndrome resulting in multiple organ failure. Increased oxidative stress has been shown after haemorrhagic shock and resuscitation, leading to inflammatory injury in organs $(2,5)$. Several factors 
including neutrophils, endothelial cells, and free oxygen radicals are responsible for IR damage (22).

Neutrophils are an important source of free oxygen radicals in the organism. Furthermore, it is suggested that neutrophils are responsible for important events involved in IR pathogenesis; including microvascular occlusion, the release of cytotoxic enzymes, increase in vascular permeability, and increased levels of released cytokines (23). Therefore, neutrophil infiltration in tissues can be considered an indicator of lung and intestinal injury after haemorrhagic shock. In the histopathological examinations in our study, it was observed that the group resuscitated with HTS 3\% had less neutrophil infiltration in the lung tissue compared to the other groups. Neutrophils contain high levels of myeloperoxidase enzyme (24).

Quantification of MPO levels provides an important parameter for the assessment of neutrophil infiltration in tissues (25). Consistent with our histopathological findings, MPO levels were found lower in the lung tissue in the HTS group in our study. It has been suggested in several studies that resuscitation with RL can activate neutrophils with a potential to increase the risk of organ injury, especially in the lungs (19). In our study, it was found that neutrophil infiltration was more intense in the lung tissue in the group resuscitated with RL. Our results are in consensus with the results reported by previous studies in the literature.

Lee et al. (26) have shown that; in shock states, neutrophils start increased synthesis of free oxygen radicals leading to acute lung injury. The activity of free oxygen radicals can be evaluated indirectly by determining the levels of MDA, which is the product of lipid peroxidation (27). In our study, MDA levels were found to be lower in lung tissues in the group resuscitated with HTS compared to the other groups. GSH is the most important antioxidant compound in the cell, protecting cells against oxidant damage. It has been shown in different conditions that HTS (7\%) increases GSH levels in lung tissues (28). Similarly, we have found higher GSH levels in the group resuscitated with HTS 3\% compared to the other groups. These findings suggest that resuscitation with HTS (3\%) has a protective effect against pulmonary IR injury associated with haemorrhagic shock. Such effects may result from actions of HTS on neutrophil functions.

HTS solutions $(3 \%, 7.5 \%)$ have high sodium content increasing plasma osmolarity. Several studies have shown that neutrophil functions can be suppressed in a hypertonic environment (14). Sato et al. (29) have shown that the synthesis of oxygen radicals in neutrophils can be suppressed dosedependently in a hypertonic environment (glucose, sucrose). Other studies have similarly reported that neutrophil functions (synthesis of oxygen radicals, phagocytosis, etc.) can be suppressed proportional to increasing plasma osmolarity (30).

The majority of studies used HTS 7.5\%; which increases plasma osmolarity more compared to HTS 3\% (11,13). However, the effects of these two different concentrations of HTS on neutrophil functions were found similar in comparative studies $(16,18)$.

Several conditions including bleeding, hypoxia, and IR stimulates TNF- $\alpha$ and IL- $1 \beta$ secretion. These cytokines induce the secretion of several proinflammatory cytokines (2).

TNF- $\alpha$ activates macrophages, stimulates granulocyte activity and neutrophil cytotoxicity, activates endothelial cells, and induces the synthesis of acute-phase proteins $(31,32)$. It is also responsible for changes in vascular resistance and permeability, hypotension, and reduction in myocardial contractility $(2,31,32)$. In our study, levels of proinflammatory cytokines (TNF- $\alpha$ and IL-1 $\beta$ ) were found lower in lung tissues in the group resuscitated with HTS compared to the other groups. These findings can be considered an indicator of the immunomodulatory effect of HTS (3\%). Similarly, previous studies have reported that the synthesis of different proinflammatory cytokines is suppressed with HTS use $(18,33)$.

Our study has some limitations. Firstly, haemodynamic parameters could not be evaluated in rats due to technical inadequacies. Secondly, indicators of intestinal IR injury (MDA, MPO, and $\mathrm{GSH}$ ) were not studied. Intestinal IR injury has been suggested as an important factor in the development of distant organ damage (34). Neutrophils are blamed as the main actors in the pathogenesis of this phenomenon. In the histopathological examinations in our study, it was observed that the group resuscitated with HTS had less neutrophil infiltration in intestinal tissues 
similar to lung tissues. Previous studies reported that resuscitation with HTS reduced intestinal IR damage and neutrophil infiltration $(16,25,35)$.

\section{Conclusion:}

Based on the results of this study, fluid resuscitation with HTS (3\%) for volume replacement in haemorrhagic shock reduces earlystage IR injury in the lungs. Furthermore, it regulates systemic inflammatory and immune system responses associated with shock favourably compared to replacement with RL. Considering these findings, replacement with HTS (3\%) can significantly reduce lung injury associated with the risk of morbidity and mortality, especially in haemorrhagic shock.

\section{REFERENCES}

1.Nunez TC, Cotton BA. Transfusion therapy in hemorrhagic shock. Current opinion in critical care. 2009;15(6):536.

2.Lenz A, Franklin GA, Cheadle WG. Systemic inflammation after trauma. Injury. 2007;38(12):13361345 .

3.Menger MD, Vollmar B. Surgical trauma: hyperinflammation versus immunosuppression? Langenbeck's archives of surgery. 2004;389(6):475484.

4.Moore FA, McKinley BA, Moore EE, et al. Inflammation and the Host Response to Injury, a large-scale collaborative project: patient-oriented research core-standard operating procedures for clinical care: III. Guidelines for shock resuscitation. Journal of Trauma and Acute Care Surgery. 2006;61(1):82-89.

5.Moore FA, McKinley BA, Moore EE. The next generation in shock resuscitation. The Lancet. 2004;363(9425):1988-1996.

6.Brøchner AC, Toft P. Pathophysiology of the systemic inflammatory response after major accidental trauma. Scandinavian journal of trauma, resuscitation and emergency medicine. 2009;17(1):1-10.

7.Kentner R, Safar P, Behringer W, et al. Early antioxidant therapy with Tempol during hemorrhagic shock increases survival in rats. Journal of Trauma and Acute Care Surgery. 2002;53(5):968-977.

8.Bilkovski RN, Rivers EP, Horst HM. Targeted resuscitation strategies after injury. Current Opinion in Critical Care. 2004;10(6):529-538.

9. Trauma AC of SurgeonsC on. Advanced Trauma Life Support Program for Doctors: ATLS. ACS; 2004. 10.Groeneveld ABJ, Polderman KH. Fluid resuscitation: the good, the bad and the ugly. Crit Care Shock. 2005;8(1):52-54.

11. de Felippe Jr J, Timoner J, Velasco IT, Lopes OU. Treatment of refractory hypovolaemic shock by $7 \cdot 5 \%$ sodium chloride injections. The Lancet. 1980;316(8202):1002-1004.

12.Shi HP, Deitch EA, Lu Q, Hauser CJ. Hypertonic saline improves intestinal mucosa barrier function and lung injury after trauma-hemorrhagic shock. Shock. 2002;17(6):496-501.

13.Vahidi E, Naderpour Z, Saeedi M. Hypertonic Saline in the Treatment of Hemorrhagic Shock. Advanced journal of emergency medicine. 2017;1(1). 14. Angle N, Hoyt DB, Coimbra R, Lui F, HerdonRemelius C, Loomis W, et al. Hypertonic saline resuscitation diminishes lung injury by suppressing neutrophil activation after hemorrhagic shock. Shock (Augusta, Ga). 1998;9(3):164-170.

15.Coimbra R, Junger WG, Hoyt DB, Liu FC, Loomis WH, Evers MF. Hypertonic Saline Resuscitation Restores Hemorrhage-Induced Immunosuppression by Decreasing Prostaglandin E2and Interleukin-4 Production. Journal of Surgical Research. 1996;64(2):203-209.

16.Han J, Ren H-Q, Zhao Q-B, Wu Y-L, Qiao Z-Y. Comparison of $3 \%$ and $7.5 \%$ hypertonic saline in resuscitation after traumatic hypovolemic shock. Shock. 2015;43(3):244-249.

17.Diehl K, Hull R, Morton $\mathrm{D}$, Pfister R, Rabemampianina Y, Smith D, et al. A good practice guide to the administration of substances and removal of blood, including routes and volumes. Journal of Applied Toxicology: An International Journal. 2001;21(1):15-23.

18. Vincenzi R, Cepeda LA, Pirani WM, Sannomyia P, Rocha-e-Silva M, Cruz Jr RJ. Small volume resuscitation with $3 \%$ hypertonic saline solution decrease inflammatory response and attenuates end organ damage after controlled hemorrhagic shock. The American journal of surgery. 2009;198(3):407414.

19.Rhee P, Burris D, Kaufmann C, Pikoulis M, Austin $B$, Ling $G$, et al. Lactated Ringer's solution resuscitation causes neutrophil activation after hemorrhagic shock. Journal of Trauma and Acute Care Surgery. 1998;44(2):313-319.

20. Ellman GL. Tissue sulfhydryl groups. Archives of biochemistry and biophysics. 1959;82(1):70-77.

21.Phillips JD, Kim CS, Fonkalsrud EW, Zeng H, Dindar H. Effects of chronic corticosteroids and vitamin A on the healing of intestinal anastomoses. The American journal of surgery. 1992;163(1):71-77.

22.Bai J, Tang L, Lomas-Neira J, Chen Y, Mc Leish $\mathrm{KR}$, Uriarte SM, et al. TAT-SNAP-23 treatment inhibits the priming of neutrophil functions contributing to shock and/or sepsis-induced extrapulmonary acute lung injury. Innate immunity. 2015;21(1):42-54.

23.Eltzschig HK, Collard CD. Vascular ischaemia and reperfusion injury. British medical bulletin. 2004;70(1):71-86.

24.Weiss SJ. Tissue destruction by neutrophils. New England Journal of Medicine. 1989;320(6):365-376. 
25.Simpson R, Alon R, Kobzik L, Valeri CR, Shepro D, Hechtman HB. Neutrophil and nonneutrophilmediated injury in intestinal ischemia-reperfusion. Annals of surgery. 1993;218(4):444.

26.Lee L, Kelher MR, Moore EE, Banerjee A, Silliman CC. Hypertonic saline inhibits arachidonic acid priming of the human neutrophil oxidase. Journal of Surgical Research. 2012;174(1):24-28.

27.Çakir Ö, Oruc A, Kaya S, Eren N, Yildiz F, Erdinc L. N-acetylcysteine reduces lung reperfusion injury after deep hypothermia and total circulatory arrest. Journal of cardiac surgery. 2004;19(3):221-225.

28.Gould N, Gauthier S, Kariya C, Min E, Huang J, Day B. Hypertonic Saline Increases Lung Epithelial Lining Fluid Glutathione and Thiocyanate: Two Protective CFTR-Dependent Thiols Against Oxidative Injury. Respiratory research. 2010; 11: 119. doi:10.1186/1465-9921-11-119

29.Sato N, Kashima K, Shimizu H, Uehara Y, Shimomura Y, Mori M. Hypertonic glucose inhibits the production of oxygen-derived free radicals by rat neutrophils. Life sciences. 1993;52(18):1481-1486.

30.Hampton MB, Chambers ST, Vissers MCM, Winterbourn CC. Bacterial killing by neutrophils in hypertonic environments. Journal of Infectious Diseases. 1994;169(4):839-846.

31.Zingarelli B, Squadrito F, Altavilla D, Calapai G, di Rosa M, Caputi AP. Role of tumor necrosis factoralpha in acute hypovolemic hemorrhagic shock in rats. American Journal of Physiology-Heart and Circulatory Physiology. 1994;266(4):H1512-H1515.

32. Rhee P, Waxman K, Clark L, Kaupke JC, Vaziri ND, Tominaga G, et al. Tumor necrosis factor and monocytes are released during hemorrhagic shock. Resuscitation. 1993;25(3):249-255.

33.Motaharinia J, Etezadi F, Moghaddas A, Mojtahedzadeh M. Immunomodulatory effect of hypertonic saline in hemorrhagic shock. DARU Journal of Pharmaceutical Sciences. 2015;23(1):47.

34.Koike K, Moore FA, Moore EE, Read RA, Carl VS, Banerjee A. Gut ischemia mediates lung injury by a xanthine oxidase-dependent neutrophil mechanism. Journal of Surgical Research. 1993;54(5):469-473.

35.Jonas J, Heimann A, Strecker U, Kempski O. Hypertonic/hyperoncotic resuscitation after intestinal superior mesenteric artery occlusion: early effects on circulation and intestinal reperfusion. Shock-Augusta. 2000;14(1):24-29. 